\title{
The Effects of Fathers' Parenting Involvement on Parenting Competence Among Mothers with Young Children: A Focus on the Moderating Effects of Couple's Communication
}

Mi-Kyung Choi

Department of Human Development and Family Studies, Duksung Women's University, Seoul, Korea

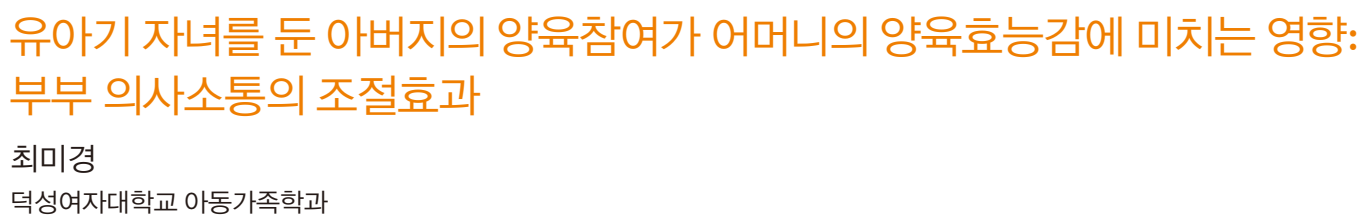

Objectives: The purpose of this study was to examine the moderating effects of couple's communication on the association between fathers' parenting involvement and mothers' parenting competence.

Methods: The subjects of the study were 289 mothers of young children in the Seoul metropolitan area. They completed questionnaires fathers' parenting involvement, couple's communication and mothers' parenting competence. Data were analyzed by means of basic descriptive statistics, Pearson's correlations, and multiple and hierarchical regression analyses. Aiken and West's method was used to determine the interactive model's modality.

Results: The major findings were as follows: First, fathers' parenting involvement was positively correlated with couple's communication and mothers' parenting competence, and couple's communication was positively correlated with mothers' parenting competence. Second, couple's communication moderated the association between fathers' parenting involvement (daily-life guidance/ leisure activity) and mothers' parenting competence even when controlling for family income

Conclusions: The findings indicate that couple's communication play an important role in buffering the negative effects of fathers' parenting involvement on mothers' parenting competence.

Keywords: fathers' parenting involvement, couple's communication, mothers' parenting competence

\section{서론}

유아기 자녀를 둔 부모의 양육행동은 이후 자녀의 성장 과정 에서도 그 기본적 특성은 유지되므로, 이 시기 부모의 양육행 동 및 양육관 정립은 중요하다. 부모가 취하는 양육행동과 밀

Corresponding Author: Mi-Kyung Choi, Department of Human Development and Family Studies, Duksung Women's University, 33 Samyangro 144-gil, Dobong-gu, Seoul, Korea

E-mail:dmkchoi@duksung.ac.kr
접한 관련이 있는 것으로 알려진, 자녀를 효율적으로 양육할 수 있다는 자신의 양육능력에 대한 믿음인 양육효능감은 자녀 의 발달에 영향이 큰 것으로 나타났다(Teti \& Gelfand, 1991). 실제로, 이 시기 대개 주양육자의 역할을 하는 어머니의 양육 효능감이 낮은 경우, 불안, 우울이 높았으며, 주위의 자원을 적

(C)The Korean Association of Child Studies

This is an Open Access article distributed under the terms of the Creative Commons Attribution Non-Commercial License (http:// creativecommons.org/licenses/by-nc/4.0) which permits unrestricted noncommercial use, distribution, and reproduction in any medium, provided the original work is properly cited. 
절히 활용하지 못했고, 억압적인 양육태도를 취해 자녀의 발 달에 부정적인 영향을 미쳤다(Coleman \& Karraker, 1997; Ha \& Jang, 2010). 반면, 양육효능감이 높은 어머니는 육아에 자신 감을 가지고 양육하여 양육스트레스가 낮았으며(An \& Kim, 2005; Cho, 2015; Coleman \& Karraker, 1997, 2003), 바람직한 양육행동을 통해 자녀의 심리, 사회적 발달에 긍정적인 영향 을 미쳤다(Dorsey, Klein, Forehand \& the Family Health Project Research Group, 1999; Lee, 2012). 양육효능감은 자녀를 양육 하는 어머니의 행복감에도 영향을 미친다고 알려진 만큼(K. S. Chung, Kim, \& Ha, 2012), 그 관련 변인을 조사하는 학문적 노 력을 통해 어머니의 양육 관련 자신감을 향상시키고 보다 효 과적인 양육을 실천하도록 도움을 제공할 필요가 있다.

어머니의 양육효능감과 관련 변인을 조사한 기존 연구들은 주로 어머니의 심리적 특성, 양육태도 및 부부관계, 그리고 자 녀의 기질과 발달 등을 중심으로 연구되었다. 어머니의 양육 효능감에 영향을 미치는 가정환경적 특성 가운데, 아버지가 양육에 얼마나 관심을 가지고 직접적으로 참여하는 지를 의미 하는 양육참여를 고려해볼 수 있다. 아버지 양육참여는 자녀 양육에 함께 보내는 물리적, 신체적 상호관계에 대한 참여행 동의 양적인 정도로, 아버지가 육아에 직접 참여하여 자녀의 생활을 지도하거나 여가를 함께 하며 돌보는 육아참여 및 아 내와 함께 가사 일을 분담하는지를 의미하는 가사활동 참여 의 개념으로 구성된다(Choi, 1992). 아버지의 양육참여는 어 머니의 양육효능감에 영향을 미치는 변인으로(Krishnakumar $\&$ Buehler, 2000), 어머니는 이를 남편에게 지지받는다고 여겨 양육을 더욱 수월하게 하는 것으로 알려졌다(Belsky, Crnic \& Woodworth, 1995). 즉, 남편이 가사나 육아에 참여하는 비중 이 높을 때, 아내는 이를 다른 사회적 관계에서 제공될 수 없는 질적으로 독특한 지원으로 여기며, 이를 토대로 형성된 부부 관계는 어머니의 적절한 양육행동으로 나타날 수 있다(Belsky, 1984). 실제로 아버지의 양육참여가 높을수록 어머니의 자 녀 양육에 대한 부담과 스트레스가 크게 감소했으며(J. S. Lee $\&$ Doo, 2008), 아버지의 양육참여로 어머니의 양육스트레스 가 낮아진 경우, 어머니의 양육효능감이 높게 나타났다(Cho, 2015). 이는 아버지의 양육참여가 높은 경우, 어머니가 양육 에 대한 높은 자신감을 보이며, 보다 효과적으로 양육행동을 할 수 있음을 나타낸다. 그러나, 자녀에게 훈육과 교육을 활발 히 시작하는 유아기 자녀를 둔 아버지의 양육참여와 어머니의 양육효능감을 직접적으로 조사한 연구는 소수에 그치며(B. S. Kim, 2011; Emery \& Tuer, 1993), 특히 아버지의 양육참여 유형 을 구분하여 이를 조사한 연구는 찾아보기 어렵다. 따라서 본
연구에서는 유아기 자녀를 둔 아버지의 양육참여가 어머니의 양육효능감에 어떠한 영향을 미치는지를 조사하였다.

또한, 어머니의 양육효능감과 관련된 변인 중, 자녀양육을 담당하는 부부간에 서로의 생각이나 느낌을 원활히 이해, 전 달하는 상호작용인 부부 의사소통(Satir, 1972)은 핵가족 내에 서 실질적으로 양육을 담당하는 부부관계의 한 특성으로 양육 신념, 양육행동과 관련된다는 점에서 주목되는 변인이다. 즉, 부부 관계적 측면이 부모의 기능을 향상 혹은 약화시킬 수 있 는 요소로 작용한다고 볼 수 있다. 실제로 부부간의 긍정성이 낮은 의사소통은 어머니의 양육효능감을 낮추었다(Planalp \& Braungart-Rieker, 2016). 또한, 부부 의사소통과 밀접한 관련이 있는 결혼만족도(Snyder, 1979)와 양육효능감을 살펴보면, 부 부가 결혼에 만족할 때 부모의 효능감은 증가했으며(A. R. Lee, 2015), 부부간의 관계가 견고할수록 양육행동이 민감하고 적 극적이며 부모로서의 능력도 높게 지각했다. 반면, 부부관계 가 불안정할 때 강제적인 양육행동을 취하거나 양육스트레스 가 높았으며(Emery \& Tuer, 1993), 부부갈등이 높을 때 어머니 의 양육 책임감이 저하되고 무력감이 높은 것으로 나타났다 (Goldberg \& Easterbrooks, 1984). 그러나, 부부관계 특성 가운 데 부부 의사소통과 어머니의 양육효능감 간의 관련성을 조사 한 국내 연구는 찾아보기 어렵다. 따라서, 가정 내의 부부 의사 소통이 양육자의 양육효능감과 관련될 수 있는지 즉, 부부간 에 긍정적이고 효율적인 의사소통을 하는 정도와 어머니의 양 육효능감과의 관련성을 조사하였다.

다음으로, 아버지의 양육참여가 부부 의사소통에 미치는 영향을 살펴보면, 두 변인을 직접 조사한 연구는 찾아보기 어 려우나, 유사한 개념인 아버지의 양육참여와 결혼만족도 및 부부관계의 연구를 통해 살펴보면, 남편이 육아에 참여를 많 이 하거나 가사 일을 돕고 가족들과 여가 활동을 함께 보낼 때, 결혼만족도가 높았으며, 부부갈등이 적었다(Ahn, 2011). 즉, 아내는 남편이 가정일에 참여할 때, 자신이 이해받고 배려받 았다고 지각하여 만족도가 높아지고(J. S. Lee, 2003) 부부관계 가 원만한 것으로 볼 수 있다. 특히, 자녀가 유아기로 접어들면 서 교육이나 양육 관련 일들이 다양해지고 많아지면서 양육부 담감을 느끼기 쉬운 유아기 자녀를 둔 어머니는 아버지가 육 아 및 가정 일에 적극적으로 참여할 때 결혼만족도가 높았으 며, 남편과 보다 긍정적인 관계를 형성했고(Ahn, 2011), 부부 에게 서로 긍정적인 의미가 있었다(Belsky, 1984). 또한, 역으 로 부부 의사소통 방식이 긍정적인 대화 형태로 자유롭게 이 루어질 때, 아버지의 양육참여를 독려하고 부정적인 양육행동 을 감소시킬 수 있었다(Chung, Kim, \& Yee, 2015). 그러나, 부 
부 의사소통이 남편의 양육참여에 미치는 영향을 조사한 연구 는 몇몇 이루어진 데에 비해, 남편의 양육참여가 부부간 의사 소통에 미치는 영향을 조사한 연구는 찾아보기 어렵다. 자녀 의 육아와 관련된 활동이 많아지고 가사부담도 늘어나는 유아 기 자녀를 둔 가정에서 직장 일로 많은 시간을 가정 밖에서 지 내는 우리나라 아버지들의 경우, 오히려 남편의 양육참여 정 도가 부부간의 관계, 즉, 의사소통의 질을 좌우할 수도 있을 것 이다. 실제로, 우리나라 아버지의 가사활동을 포함하여 육아 에 참여하는 비율이 다른 $\mathrm{OECD}$ 국가들과 비교할 때 최저 수 준이라는 보고가 있었다(The Asia Business Daily, 2014). 따라서 본 연구에서는 유아기 자녀를 둔 어머니를 대상으로 남편의 양육참여의 하위요인들과 부부 의사소통이 어떠한 관계를 나 타내는지를 조사하였다.

한편, 자녀 양육과정에서 형성되는 양육효능감과 같은 어 머니의 내적 신념체계의 발달은 부부관계에 따라 그 결과가 달리 나타나기도 한다. 즉, 유아기 어머니가 남편이 자신을 잘 이해하고 지지해준다고 여기며 애정적이라고 느끼는지에 따 라 어머니의 양육효능감의 정도는 달라질 수 있다는 것이다. 아버지 양육참여와 부부 의사소통, 그리고 어머니의 양육효능 감을 모두 함께 조사한 연구는 찾아볼 수 없지만, 부부 의사소 통과 유사한 개념인 부부 관계를 통해 유추해 볼 수 있다. 즉, 아버지의 양육참여가 어머니의 양육스트레스에 영향을 미치 는 과정에서 부부관계가 영향을 미쳤으며, 이러한 관계는 사 회적지지 정도에 따라 달리 나타났다(E. J. Kim, Park, \& Kim, 2014). 또한, 아버지의 양육참여가 양육효능감에 영향을 미 치는 과정에서 결혼만족도 수준이 관계가 있었다(Sevigny \& Loutzenhiser, 2010). 이러한 연구는 자녀를 함께 양육하는 남편 이 양육에 적극적으로 참여하는 것이 아내의 양육에 영향을 미치며, 이 과정에서 부부관계에 따라 어머니가 느끼는 양육 부담감 등을 달라지게 하는 중요한 요인이 될 수 있음을 예상 하게 한다. 그러나, 어머니 양육효능감의 결정요인으로 아버 지 양육참여와 부부 의사소통의 상호작용을 조사한 연구는 찾 아볼 수 없다. 따라서 본 연구에서는 자녀의 교육과 훈육이 본 격적으로 시작되는 유아기 자녀를 둔 어머니를 대상으로 아버 지 양육참여가 어머니의 양육효능감에 미치는 영향에서 부부 의사소통의 조절효과를 조사했다.

이상에서 살펴본 바와 같이, 아버지의 양육참여 및 부부 의 사소통은 각각 어머니의 양육효능감과 밀접하게 관련될 뿐만 아니라, 아버지의 양육참여와 어머니의 양육효능감 간의 관계 에서 부부 의사소통이 중재적 역할을 할 수 있을 것이다. 이에 본 연구에서는 유아기 자녀를 둔 어머니를 대상으로 아버지의
양육참여와 부부 의사소통이 각각 어머니의 양육효능감과 어 떠한 관계가 있는지를 확인하였다. 이와 더불어, 아버지 양육 참여와 어머니의 양육효능감 간의 관계에서 부부 의사소통의 조절효과를 조사했다.

본 연구에서 선정한 연구문제는 다음과 같다.

\section{연구문제 1}

유아기 자녀를 둔 아버지의 양육참여, 부부 의사소통과 어머 니의 양육효능감은 어떠한 관계가 있는가?

\section{연구문제 2}

유아기 자녀를 둔 부부 의사소통은 아버지의 양육참여와 어 머니의 양육효능감 간의 관계를 조절하는가?

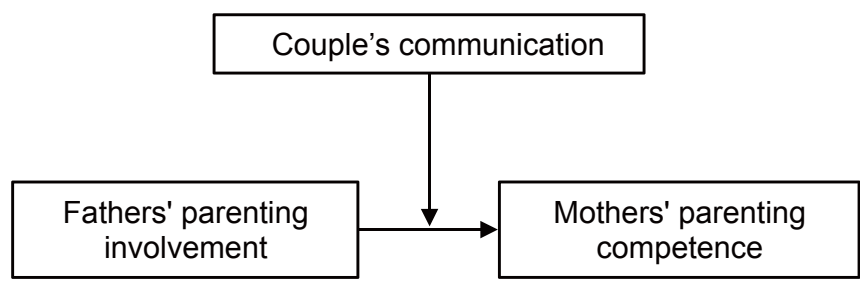

Figure 1. Study model for the moderating effects of couple's communication

\section{연구방법}

\section{연구대상}

본 연구의 대상은 서울시 $\mathrm{D}, \mathrm{Y}$ 구에 위치한 어린이집 13 기관 에 다니는 자녀를 둔 유아기 자녀의 어머니 289 명이었다. 본 연구의 대상을 유아기 자녀를 둔 어머니로 선정한 것은, 이 시 기 어머니가 자녀를 본격적으로 훈육, 교육하며 이러한 양육 활동의 경험을 통해 양육효능감을 형성해가고, 부부간에 육 아로 인해 역할분담이 요구되는 시기이기 때문이다(Doh, et al., 2011). 연구대상자의 사회인구학적 특성을 살펴보면, 유아 기 자녀의 성별은 남아가 153 명(55.3\%), 여아가 132명(45.7\%) 이었다. 유아의 연령은 5세가 133 명(45.8\%)으로 가장 많았 으며 4세가 96명(33.2\%), 3세가 61명(21.0\%) 순으로 나타났 다. 아버지의 연령은 36-40세가 109 명(37.9\%)로 가장 많았으 며 41-45세가 74명(25.6\%), 30-35세가 74명(25.6\%)으로 나타 났다. 어머니의 연령은 36-40세가 136명(47.0\%)로 가장 많았 으며 30-35세가 85명(29.4\%), 41-45세가 42명(14.5\%)의 순으 로 나타났다. 아버지의 학력은 대학교 졸업이 129 명(44.6\%), 
Table 1

Demographic Characteristics of Participants

\begin{tabular}{|c|c|c|c|}
\hline Variables & $N(\%)$ & Variables & $N(\%)$ \\
\hline $\begin{array}{l}\text { Child's gender } \\
\text { Boys } \\
\text { Girls }\end{array}$ & $\begin{array}{l}153(55.3) \\
132(45.7)\end{array}$ & $\begin{array}{l}\text { Child's age } \\
3 \text { years } \\
4 \text { years } \\
5 \text { years }\end{array}$ & $\begin{array}{r}61(21.0) \\
96(33.2) \\
133(45.8) \\
\end{array}$ \\
\hline $\begin{array}{l}\text { Father's age } \\
\text { Under } 30 \text { years } \\
30-35 \text { years } \\
36-40 \text { years } \\
41-45 \text { years } \\
\text { 46-50 years } \\
51-55 \text { years } \\
\text { Over } 56 \text { years } \\
\text { Missing }\end{array}$ & $\begin{array}{r}6(2.1) \\
74(25.6) \\
109(37.8) \\
74(25.7) \\
23(7.9) \\
1(0.3) \\
1(0.3) \\
1(0.3)\end{array}$ & $\begin{array}{l}\text { Mother's age } \\
\text { Under } 30 \text { years } \\
\text { 30-35 years } \\
36-40 \text { years } \\
41-45 \text { years } \\
\text { 46-50 years } \\
51-55 \text { years } \\
\text { Over } 56 \text { years } \\
\text { Missing }\end{array}$ & $\begin{aligned} & 11(3.8) \\
& 85(29.5) \\
& 136(47.1) \\
& 42(14.5) \\
& 10(3.5) \\
& 1(0.3) \\
& 1(0.3) \\
& 3(1.0)\end{aligned}$ \\
\hline $\begin{array}{l}\text { Father's educational level } \\
\text { Middle school } \\
\text { High school } \\
\text { College } \\
\text { University } \\
\text { Graduate school } \\
\text { Missing } \\
\end{array}$ & $\begin{array}{r}1(0.3) \\
62(21.5) \\
52(18.0) \\
129(44.6) \\
42(14.5) \\
3(1.0) \\
\end{array}$ & $\begin{array}{l}\text { Mother's educational level } \\
\text { middle school } \\
\text { High school } \\
\text { College } \\
\text { University } \\
\text { Graduate school } \\
\text { Missing }\end{array}$ & $\begin{array}{r}3(1.0) \\
60(20.8) \\
74(25.6) \\
115(39.8) \\
34(118) \\
3(1.0)\end{array}$ \\
\hline $\begin{array}{l}\text { Father's occupation } \\
\text { Unemployed } \\
\text { Labor } \\
\text { Device/machine operation } \\
\text { and assembly workers } \\
\text { Sale service } \\
\text { Accountant security } \\
\text { Directorate office } \\
\text { Occupation professional } \\
\text { Service } \\
\text { Other } \\
\text { Missing }\end{array}$ & $\begin{array}{r}4(1.4) \\
7(2.4) \\
35(12.1) \\
44(15.2) \\
19(6.6) \\
98(33.9) \\
45(15.9) \\
8(2.8) \\
18(6.2) \\
10(3.2)\end{array}$ & $\begin{array}{l}\text { Mother's occupation } \\
\text { Unemployed } \\
\text { Labor } \\
\text { Device/machine operation } \\
\text { and assembly workers } \\
\text { Sale service } \\
\text { Accountant security } \\
\text { Directorate office } \\
\text { Occupation professional } \\
\text { Service } \\
\text { Other } \\
\text { Missing }\end{array}$ & $\begin{array}{r}110(38.1) \\
7(2.4) \\
21(7.3) \\
\\
21(7.3) \\
18(6.2) \\
51(17.6) \\
39(13.5) \\
3(1.0) \\
9(3.1) \\
10(3.2)\end{array}$ \\
\hline $\begin{array}{l}\text { Income } \\
\text { Less than } 3 \text { million won } \\
3 \text { million won - less than } 4 \text { million won (b) } \\
4 \text { million won - less than } 5 \text { million won (c) } \\
\text { More than } 5 \text { million won }(\mathrm{d})\end{array}$ & $\begin{array}{r}47(16.4) \\
77(26.8) \\
50(17.5) \\
113(39.3)\end{array}$ & & \\
\hline
\end{tabular}

Note. $N=289$.

고등학교 졸업이 62명(21.5\%), 전문대 졸업이 52명(18.0\%) 의 순으로 나타났다. 어머니의 학력은 대학교 졸업이 115 명 (39.8\%), 전문대 졸업이 74 명(25.6\%), 고등학교 졸업이 60명 (20.8\%)로 나타났다. 아버지의 직업은 회사원이 98 명(33.9\%) 로 가장 많았으며 다음은 전문직이 45 명(15.9\%)였고, 그 다 음으로는 판매직이 44 명(15.2\%)의 순으로 나타났다. 어머니 의 직업은 전업주부가 110 명 $(38.1 \%)$ 로 가장 많았으며 다음 은 회사원이 51명 $(17.6 \%)$ 였고, 그 다음으로는 전문직이 39명 (13.5\%)의 순으로 나타났다. 가정의 월소득은 500 만원 이상이
113 명(39.3\%), 300-400만원 미만이 77명(26.8\%), 400-500만원 미만이 50명(17.5\%), 300만원 미만이 47 명(16.4\%)의 순으로 나타났다.

\section{조사도구}

본 연구의 설문지는 아버지의 양육참여, 부부 의사소통, 그리 고 양육효능감 척도로 구성되었다. 본 척도는 유아기 자녀를 둔 어머니가 지각하는 바를 측정하기 위해 어머니들에 의해 
평가되었다.

\section{아버지의 양육참여}

본 연구에서 사용한 아버지 양육참여 질문지는 Bigner (1977), Baruch와 Barnett (1981), Lamb (1975)의 연구를 토대로 제작된 K. S. Choi (1992)의 도구를 유아기 자녀를 둔 아버지용으로 수 정·보완한 Yoon (2014)의 도구를 사용하였다. 이 척도는 아버 지의 양육참여 정도를 묻는 질문지로 생활지도, 가사활동, 여 가활동의 3 개 하위 척도로 구성되어 있다. 설문지 문항들은 설문지 실시에 앞서 아동학자 두 명이 검토하여 안면타당도 를 확보하였다. 아버지 양육참여 하위요인의 구인타당도를 확 인하고자 요인분석실시에 앞서 $\mathrm{KMO}$ (Kaiser Meyer Olkin)와 Bartlett의 구형성 검정치를 산출하였다. 그 결과 각각.93과 $p$ <.001로 나타나 요인분석을 실시하기에 적합하였다. 아버지 양육참여 하위요인의 구인타당도를 확인하기 위해 요인부하 량을 .40 이상으로 하여 요인분석을 실시한 결과, 모든 문항의 공유치가 . 40 을 초과하였다. 그러나, 본 분석 시 신뢰도를 낮추 는 4 개 문항이 나타나 이들 요인은 제외되었다. 아버지 양육참 여는 생활지도(11문항; .47 .74), 가사활동(4문항; .78 .81), 여가활동(6문항; .64 .78)의 3개 하위요인 총 21문항으로 구 성되었다. 또한, 아버지 양육참여 척도의 구성요인 간의 상관 관계를 조사한 결과, 상관관계는 . $45 \sim .70$ 의 유의한 상관 $(p<$ $.001)$ 을 나타내었다. 이는 다중공선성 검증 기준 $(r<.80$; Berry \& Feldman, 1985)에 적합한 수치이다.

척도 문항의 예를 살펴보면, 유아가 사회생활을 해나가는 데 필요한 기본예절지도, 언행지도, 일상생활습관 형성 등을 위해 도움을 주는 일인 생활지도는 "자녀가 실수했을 때 잘한 점과 잘못한 점을 자상하게 가르쳐준다.", "어떤 일에 대해서 자녀와 함께 이야기하거나 생각하기를 좋아한다.” 등이며, 식 사준비, 설거지, 집안청소 등에 참여하는 것을 의미하는 가사 활동은 “설거지를 돕는다.”, “세탁을 돕는다.” 등이고 자녀와 함께 나들이, 동, 식물원, 유원지, 놀이터 등에서 함께 즐기는 활동을 뜻하는 여가활동은 "자녀와 함께 공원이나 놀이터에 간다.", “자녀와 함께 동, 식물원이나 박물관에 간다.” 등으로 구성되었다. 각 문항은 전혀 그렇지 않다(1점)에서 매우 그렇 다(5점)까지의 Likert식 5점 척도로 측정되었다. Yoon \& Sung (2014)의 연구에서 각 하위요인 각각의 Cronbach's $\alpha$ 는 생활지 도 .88 , 가사활동 .82 , 그리고 여가활동 .90 이였으며, 본 연구에 서는 생활지도 .88 , 가사활동 .86 , 그리고 여가활동 .90 으로 나 타났다.

\section{부부 의사소통}

본 연구에서 사용한 부부 의사소통 질문지는 Bienvenu (1970) 가 개발한 부부 의사소통 측정도구(Marital Communication Inventory, [MCI])를 S. S. Lee (2016)의 연구에서 수정, 보완하 여 재구성한 척도를 사용하였다. 이 척도는 언어적, 비언어적 의사소통과 감정의 이해, 경청의 자세에 대한 내용을 포함하 고 있으며 총 15 문항으로 구성되어 있다. 부정적인 문항은 역 산 처리하여 점수가 높을수록 긍정적, 효율적인 의사소통을 한다는 것을 뜻한다.

개별 문항의 예를 살펴보면, "남편은 나의 감정을 잘 이해 해주는 편이다.", "나와 남편은 서로의 개인적인 문제를 상의 한다.” 등으로 구성되었다. 각 문항은 전혀 그렇지 않다(1점) 에서 언제나 그렇다(4점)까지의 Likert식 4점 척도로 측정되었 다. S. S. Lee (2016) 연구의 Cronbach's $\alpha$ 는 .85였으며, 본 연구 에서는 .89로 나타났다.

양육효능감

본 연구 하위변인인 어머니의 양육효능감은 Floyd, Gilliom과 Costigan (1998)이 개발한 'Perceived Parenting Competence'를 J. Y. Ahn (2002)이 번안, 수정한 척도를 사용하였다. 이 척도는 부모 역할에 대한 자신감 요인(Parenting Confidence Scale)과 어려움 요인(under control scale)이 포함되었으며 총 15문항으 로 구성되었다.

각 문항의 예를 살펴보면, “좋은 부모가 되는데 필요한 지 식을 잘 알고 있다., "다시 아이를 키우더라도 내가 지금 아 이를 키우는 방식으로 키울 것이다.” 등으로 구성되었다. 각 문항은 전혀 그렇지 않다(1점)에서 매우 그렇다(5점)까지의 Likert식 5점 척도로 측정되었다. 본 연구 분석 시 부정적 문항 은 역코딩 하였다. J. Y. Ahn (2002)의 연구에서 Cronbach's $\alpha$ 는 .78이였으며, 본 연구에서는 .81로 나타났다.

\section{조사 절차 및 자료분석}

본 연구의 조사는 2017년 7월 10월에 서울시 D, Y구에 위치 한 국공립, 민간 어린이집 13 기관에 재원 중인 3세 5세 유아 의 어머니를 대상으로 실시하였다. 설문지를 실시하기에 앞서 각 어린이집 원장님께 사전에 동의와 협조를 구한 후, 설문지 의 목적과 내용을 설명해 드렸다. 설문지는 어린이집 원장님 
Table 2

Difference of Parenting Competence According to Income

\begin{tabular}{llcccc}
\hline \multicolumn{1}{c}{ Variables } & $n$ & $M$ & $S D$ & $F$ & Scheffé \\
\hline Income & Less than 3 million won (a) & 47 & 2.49 & .38 & $6.97^{* * *}$ \\
& 3 million won - Less than 4 million won (b) & 77 & 2.64 & .35 & a b,c,d \\
4 million won - Less than 5 million won (c) & 50 & 2.67 & .33 & .33 \\
More than 5 million won (d) & 113 & 2.77 & \\
\hline
\end{tabular}

Note. $N=289$.

*** $p<.001$.

들에게 직접 혹은 우편으로 배부하였으며, 설문지 실시에 앞 서 원장 및 교사 세 명이 검토한 후, 세 명의 어머니에게 간단 히 실시해 보도록 하였다. 배부된 설문지는 담임교사를 통해 각 가정의 어머니에게 전달되어 2주 후 회수하였다. 모두 400 부의 질문지가 배부되었으며 362부가 회수되었으나(회수율: $98.3 \%)$, 이 중 이혼, 별거 가정이거나 불성실하게 응답한 73 부를 제외시키고, 총 289부를 본 연구에서 분석하였다.

수집된 자료는 SPSS 24.0 (IBM Co., Armonk, NY)으로 분석 하였다. 연구대상자의 사회인구학적 특성을 살펴보기 위해 빈 도, 백분율, 평균 및 표준편차를 산출하였고, 조사도구의 신뢰 도를 알아보기 위해 Cronbach's $\alpha$ 를 산출하였다. 또한, 어머니 취업여부 및 어머니의 연령, 교육수준, 및 가정의 월평균 수입 에 따른 양육효능감의 차이를 알아보기 위해 $\mathrm{T}$ 검정과 분산분 석을 실시하였다. 이와 함께, 아버지의 양육참여, 부부 의사소 통과 어머니의 양육효능감 간의 관계를 조사하기위해 Pearson 의 적률상관계수를 산출하였다. 마지막으로, 아버지의 양육참 여와 부부 의사소통이 어머니의 양육효능감에 어떠한 영향을 미치는지 조사하기 위해 변인들을 독립, 종속변인으로 구분한 후, 단순, 위계적 회귀분석을 실시하였다.

\section{연구결과}

\section{기초분석}

어머니의 연령, 취업여부, 교육수준 및 가정의 월평균 소득이 어머니의 양육효능감에 영향을 미친다는 선행 연구를 기초 로(Ponnet et. al., 2013), 어머니의 연령, 교육수준 및 월평균 가 구소득에 따른 어머니의 양육효능감을 살펴보았다. 그 결과, 어머니의 연령, 취업여부, 교육수준은 어머니의 양육효능감 에 유의한 영향을 미치지 않았으나, 월평균 가구소득에 따라 어머니의 양육효능감에 차이가 나타났다 $(F=6.97, p<.001)$.
집단 간의 구체적인 관계를 파악하기 위해 Scheffé 검증 결과 Table 2와 같이 300 만원 미만의 소득집단과 300 만원 이상의 소득집단 간에 유의한 차이가 나타나 300 만원 미만의 소득집 단에 비해 300 만원 이상의 소득집단 어머니의 양육효능감이 높았다.

\section{유아기 자녀를 둔 아버지의 양육참여, 부부 의사소통과 어머니 양육효능감 간의 관계}

아버지의 양육참여 및 부부 의사소통과 어머니 양육효능감 간 의 관계를 살펴본 결과, Table 3과 같이 아버지 양육참여의 하 위요인(생활지도: $r=.27, p<.001$, 가사활동: $r=.16, p<.01$, 여가활동: $r=.19, p<.001)$ 은 어머니 양육효능감과 정적상관 을 나타냈다. 부부 의사소통도 어머니의 양육효능감 $(r=.36, p$ $<.001)$ 과 정적상관을 나타냈다. 또한, 아버지 양육참여의 하 위요인(생활지도: $r=.43, p<.001$, 가사활동: $r=.23, p<.001$, 여가활동: $r=.37, p<.001)$ 은 부부 의사소통과 정적 상관관계 를 나타냈다. 즉, 아버지가 가정 내 자녀의 생활지도, 가사활동 그리고 여가활동에 많이 참여할수록 그리고, 부부가 긍정적인 의사소통을 많이 할수록 어머니의 양육효능감은 높게 나타났 다. 나아가, 아버지가 집안에서 자녀의 생활지도를 하며 가사 및 여가활동에 더 많이 참여할수록 부부간에 보다 긍정적인 대화를 하는 것으로 나타났다.

\section{유아기 자녀를 둔 아버지의 양육참여와 어머 니의 양육효능감 간의 관계에서 부부 의사소 통의 조절효과}

아버지의 양육참여와 어머니의 양육효능감 간의 관계에서 부 부 의사소통의 조절효과를 살펴보기 위해, 어머니의 양육효능 감을 종속변인으로 하여 Aiken과 West (1991)가 제시한 방식 으로 위계적 회귀분석을 실시하였다. 이때, 다중회귀분석에서 
Table 3

Correlation Between Fathers' Parenting Involvement, Couple's Communication, and Mothers' Parenting Competence

\begin{tabular}{lccccc}
\hline \multicolumn{1}{c}{ Variables } & 1 & 2 & 3 & 4 & 5 \\
\hline 1. Daily-life guidance & - & & & & \\
2. Housekeeping activity & $.51^{* * *}$ & - & & & \\
3. Leisure activity & $.70^{* * *}$ & $.45^{* * *}$ & - & & \\
4. Couple's communication & $.43^{* * *}$ & $.23^{* * *}$ & $.37^{* * *}$ & - & - \\
5. Mothers' parenting competence & $.27^{* * *}$ & $.16^{* *}$ & $.19^{* * *}$ & $.36^{* * *}$ & - \\
\hline$M(S D)$ & $3.68(.67)$ & $3.20(.92)$ & $3.95(.72)$ & $2.92(.44)$ & $2.67(.35)$ \\
\hline
\end{tabular}

Note. $N=289$.

${ }^{* *} p<.01{ }^{* * *} p<.001$.

발생할 수 있는 다중공선성의 문제를 피하고 분석의 신뢰성을 높이기 위해(Hong, 2005), 상호작용 항은 두 독립변수를 평균 중심화(mean centering) 하여 그 값을 곱하였다. 먼저, Baron과 Kenny (1986)가 제안한 절차에 따라, 1 단계에서는 월평균 가 구소득을 통제변인으로 투입하였으며, 2단계에서는 아버지 의 양육참여와 부부 의사소통을 투입하였고, 3 단계에서 아버 지의 양육참여와 부부 의사소통의 상호작용 항을 투입하였다. 다중공선성의 위반여부를 확인하고자, 공차(tolerance)와 분산 팽창계수(variance inflation factor)를 검토한 결과, 0.1 이상(.73 .98)과 10이하(1.02 1.38)로 나타나 회귀분석을 실시하기 에 적합하였다(Berry \& Feldman, 1985). 어머니의 양육효능감 에 대해 상호작용 효과가 나타난 독립변인인 아버지 양육참여 (생활지도, 여가활동)과 부부 의사소통의 상호작용 효과를 하 위변인 순으로 제시하면 다음과 같다.

유아기 자녀를 둔 아버지 양육참여(생활지도)와 어머니의 양육효능감 간의 관계에서 부부 의사 소통의 조절효과

아버지의 생활지도와 어머니의 양육효능감과의 관계에서 부 부 의사소통의 조절효과를 검증한 결과 Table 4 와 같이, 1 단계 에서 월평균 가구소득은 어머니의 양육효능감에 유의한 영향 을 미치는 것으로 나타났으며 $(\beta=.18, p<.001)$, 어머니의 양 육효능감을 $4 \%$ 설명했다. 2 단계에서 아버지의 생활지도와 부부 의사소통을 투입했을 때, 월평균 가구소득은 어머니의 양육효능감에 여전히 정적 영향을 미쳤으며 $(\beta=.12, p<.05)$, 아버지의 생활지도도 어머니의 양육효능감에 정적 영향을 미 쳤고 $(\beta=.16, p<.01)$, 부부 의사소통 역시 어머니의 양육효능 감에 정적 영향을 미쳤다 $(\beta=.26, p<.001)$. 어머니 양육효능
감에 대한 전체 설명력은 $17 \%$ 였다. 3 단계에서 아버지의 생활 지도와 부부 의사소통 간 상호작용 변인을 투입했을 때, 월평 균 가구소득 $(\beta=.11, p<.01)$, 아버지의 생활지도 $(\beta=.18, p<$ $.01)$, 부부 의사소통 $(\beta=.24, p<.001)$, 그리고 아버지의 생활지 도와 부부 의사소통 간 상호작용 변인 $(\beta=.15, p<.01)$ 은 모두 유의하였고, 전체 설명력은 $2 \%$ 증가해 $19 \%$ 였다. 이는 아버 지의 생활지도가 어머니의 양육효능감에 미치는 영향이 부부 의사소통 수준에 따라 달라짐을 뜻한다.

어머니의 양육효능감에 대한 아버지 생활지도와 부부 의 사소통의 상호작용 효과를 보다 구체화하기 위해, Aiken과 West(1991)의 회귀방정식을 활용하여 다음과 같이 제시하였 다. 먼저, 부부 의사소통의 평균에서 $+1 S D$ 와 - $1 S D$ 를 기준으 로 상, 하 집단으로 구분하여 두 개의 회귀식을 생성하였다. 그 결과, 부부 의사소통의 긍정성 수준이 낮은 집단과 부부 의사 소통의 긍정성 수준이 높은 집단 모두 아버지의 생활지도는 어머니의 양육효능감에 정적 영향을 미쳤다 $(\beta=.41, p<.001$, $\beta=.49, p<.001)$. 먼저 Figure 2 와 같이, 아버지가 유아기 자녀 의 생활지도에 많이 참여할 경우, 부부 의사소통의 긍정성 수 준이 높은 집단은 긍정성 수준이 낮은 집단에 비해 어머니의 양육효능감이 더 높은 것으로 나타났다. 또한, 아버지가 유아 기 자녀의 생활지도에 적게 참여할 경우에도 부부 의사소통 의 긍정성 수준이 높은 집단은 긍정성 수준이 낮은 집단에 비 해 어머니의 양육효능감이 더 높았다. 이는 같은 수준으로 아 버지가 자녀의 생활지도에 참여해도, 부부 의사소통의 긍정성 수준이 높을수록 어머니의 양육효능감이 더 높음을 나타내는 결과이다.

유아기 자녀를 둔 아버지 양육참여(여가활동) 와 어머니의 양육효능감 간의 관계에서 부부 
Table 4

Moderating Effect of Couple's Communication in the Relationship Between Fathers' Parenting Involvement (Daily-life Guidance) and Mothers' Parenting Competence

\begin{tabular}{|c|c|c|c|c|c|c|c|}
\hline Dependent variables & Step & Independent variables & $B(S E)$ & $\beta$ & $R^{2}$ & $\Delta R^{2}$ & $F$ \\
\hline \multirow{8}{*}{$\begin{array}{l}\text { Mothers' parenting } \\
\text { competence }\end{array}$} & 1 & Family income & $.11(.03)$ & $.18^{* * *}$ & $.04^{* * *}$ & & $4.03^{* *}$ \\
\hline & 2 & Family income & $.07(.03)$ & $.12^{*}$ & $.17^{* * *}$ & .13 & $10.89^{* * *}$ \\
\hline & & Daily-life guidance & $.09(.03)$ & $.16^{* *}$ & & & \\
\hline & & Couple's communication & $.20(.05)$ & $.26^{* * *}$ & & & \\
\hline & 3 & Family income & $.06(.03)$ & $.11^{* *}$ & $.19^{* *}$ & .02 & $10.54^{* * *}$ \\
\hline & & Daily-life guidance & $.10(.03)$ & $.18^{* *}$ & & & \\
\hline & & Couple's communication & $.19(.04)$ & $.24^{* * *}$ & & & \\
\hline & & Daily-life guidance $\times$ Couple's communication & $.16(.06)$ & $.15^{* *}$ & & & \\
\hline
\end{tabular}

Note. $N=289$.

${ }^{*} p<05 .{ }^{* *} p<.01 .{ }^{* * *} p<.001$.
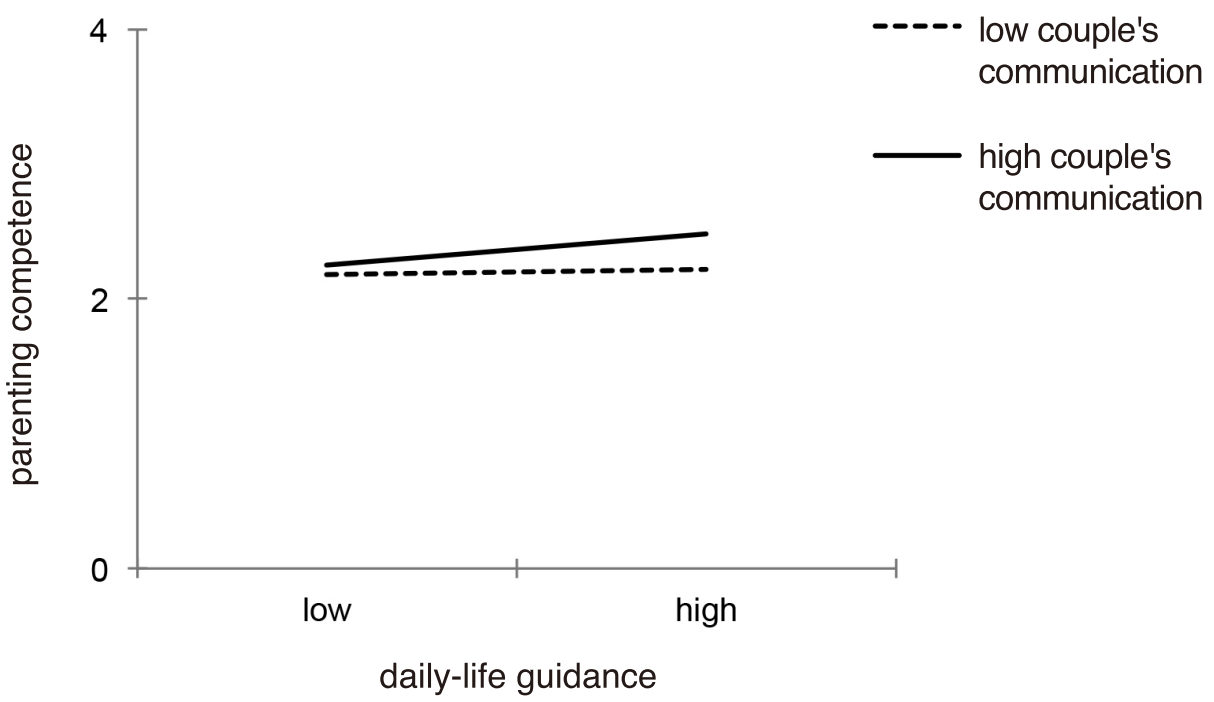

Figure 2. Moderating effects of couple's communication in the relationship between fathers' parenting involvement (daily-life guidance) and mothers' parenting competence

\section{의사소통의 조절효과}

아버지의 여가활동 참여와 어머니의 양육효능감 간의 관계에 서 부부 의사소통의 조절효과를 검증한 결과, 1 단계에서 월평 균 가구소득은 어머니의 양육효능감에 유의한 영향을 미치는 것으로 나타났으며 $(\beta=.18, p<.01)$, 어머니의 양육효능감을 4 $\%$ 설명했다. 2 단계에 아버지의 여가활동 참여와 부부 의사소 통을 투입했을 때, 월평균 가구소득은 어머니의 양육효능감에 정적 영향을 미쳤으며 $(\beta=.12, p<.05)$, 아버지의 여가활동 참 여는 어머니의 양육효능감에 유의한 영향을 미치지 않았고 ( $\beta$ $=.10, p>.05)$, 부부 의사소통은 어머니의 양육효능감에 정적
영향을 미치는 것으로 나타났다 $(\beta=.29, p<.001)$. 어머니의 양육효능감에 대한 전체 설명력은 $16 \%$ 였다. 3 단계에서 아버 지의 여가활동 참여와 부부 의사소통 간 상호작용 변인을 투 입했을 때, 월평균 가구소득 $(\beta=.11, p<.05)$, 아버지의 여가활 동 참여 $(\beta=.14, p<.05)$, 부부 의사소통 $(\beta=.28, p<.001)$, 그리 고 아버지의 여가활동 참여와 부부 의사소통 간 상호작용 변 인 $(\beta=.17, p<.01)$ 은 유의하였으며 전체 설명력은 $3 \%$ 증가 해 $19 \%$ 였다. 이는 아버지의 여가활동 참여가 어머니의 양육 효능감에 미치는 영향이 부부 의사소통 수준에 따라 달라짐을 의미한다.

어머니의 양육효능감에 대한 아버지 여가활동 참여와 부 
Table 5

Moderating Effect of Couple's Communication in the Relationship Between Fathers' Parenting Involvement (Leisure Activity) and Mothers' Parenting Competence

\begin{tabular}{|c|c|c|c|c|c|c|c|}
\hline Dependent variables & Step & Independent variables & $B(S E)$ & $\beta$ & $R^{2}$ & $\Delta R^{2}$ & $F$ \\
\hline \multirow{8}{*}{$\begin{array}{l}\text { Mothers' parenting } \\
\text { competence }\end{array}$} & 1 & Family income & $.11(.03)$ & $.18^{* *}$ & $.04^{* * *}$ & & $3.75^{* *}$ \\
\hline & 2 & Family income & $.07(.03)$ & $.12^{*}$ & $.16^{* * *}$ & .12 & $10.04^{* * *}$ \\
\hline & & Leisure activity & $.05(.03)$ & .10 & & & \\
\hline & & Couple's communication & $.23(.04)$ & $.29^{* * *}$ & & & \\
\hline & 3 & Family income & $.06(.03)$ & $.11^{*}$ & $.19^{* *}$ & .03 & $10.29^{* * *}$ \\
\hline & & Leisure activity & $.07(.03)$ & $.14^{*}$ & & & \\
\hline & & Couple's communication & $.22(.04)$ & $.28^{* * *}$ & & & \\
\hline & & Leisure activity $\times$ Couple's communication & $.17(.05)$ & $.17^{* *}$ & & & \\
\hline
\end{tabular}

Note. $N=289$.

${ }^{*} p<05 .{ }^{* *} p<.01 .{ }^{* * *} p<.001$.

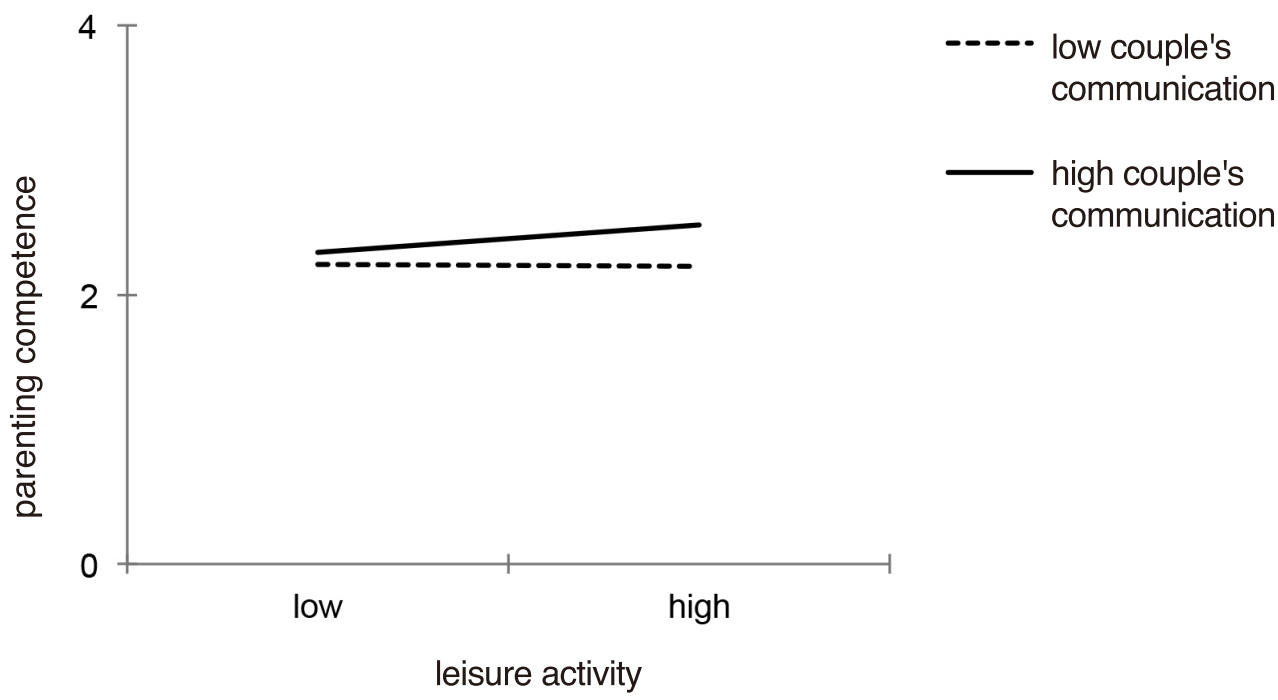

Figure 3. Moderating effects of couple's communication in the relationship between fathers' parenting involvement (leisure activity) and mothers' parenting competence

부 의사소통의 상호작용 효과를 구체화하기 위해, Aiken과 West(1991)가 제안한 절차에 따라 다음과 같이 제시하였다. 먼 저, 부부 의사소통의 평균에서 $+1 S D$ 와 - $1 S D$ 를 기준으로 상, 하 집단으로 구분하여 두 개의 회귀식을 생성하였다. 그 결과, 부부 의사소통의 긍정성 수준이 낮은 집단과 부부 의사소통의 긍정성 수준이 높은 집단 모두 아버지의 여가활동 참여는 어 머니의 양육효능감에 정적 영향을 미쳤다 $(\beta=.41, p<.001, \beta$ $=.49, p<.001)$. 먼저 Figure 3 과 같이, 아버지가 유아기 자녀의 여가활동에 많이 참여할 경우, 부부 의사소통의 긍정성 수준 이 높은 집단은 긍정성 수준이 낮은 집단에 비해 어머니의 양 육효능감이 더 높은 것으로 나타났다. 또한, 아버지가 유아기
자녀의 여가활동에 적게 참여할 경우에도 부부 의사소통의 긍 정성 수준이 높은 집단은 긍정성 수준이 낮은 집단에 비해 어 머니의 양육효능감이 더 높았다. 즉, 같은 정도로 아버지가 자 녀의 여가활동에 참여해도, 부부 의사소통의 긍정성 수준이 높을수록 어머니의 양육효능감이 더 높았다. 이와 같은 결과 는 부부 의사소통이 긍정적이라는 어머니의 지각이 아버지의 생활지도나 여가활동 참여수준이 어머니의 양육효능감에 미 치는 긍정적인 영향을 더 강화하는 효과가 있음을 나타낸다. 그러나, 아버지의 가사활동 참여와 어머니의 양육효능감과의 관계에서 부부 의사소통의 조절효과는 나타나지 않았다. 


\section{논의 밋 결론}

본 연구에서는 유아기 자녀를 둔 어머니를 대상으로 아버지의 양육참여 및 부부 의사소통이 각각 어머니의 양육효능감과 어 떠한 관련이 있는지 및 아버지의 양육참여가 부부 의사소통 과 어떠한 관계가 있는지를 조사하였다. 또한, 아버지의 양육 참여가 어머니의 양육효능감에 미치는 영향에서 부부 의사소 통이 중재역할을 하는지를 살펴보았다. 본 연구의 연구문제를 중심으로 결과를 요약하고 논의하면 다음과 같다.

첫째, 본 연구의 기초분석에서 월평균 가구소득이 어머니 의 양육효능감에 유의한 영향을 미쳐 월평균 가구소득이 많 을수록 어머니의 양육효능감이 높았다. 특히, 월평균 가구소 득이 300 만원 미만과 이상의 소득집 간에 유의한 차이가 나타 났는데, 이는 어머니의 양육효능감이 월평균 가구소득에 따 라 차이가 나타난 연구(Ponnet et, al., 2013; Hong \& Yi, 2017) 와 유사한 결과이다. 또한, 일정한 금액 즉, 월평균 가구소득이 300 만원 미만인 경우, 어머니의 양육효능감은 더 취약한 것으 로 조사되었다. 이는 빈곤층의 최저생활에 대한 보장을 위해 준거점으로 작용하는 최저생계비가(C. J. Kim \& Son, 2011) 4 인가족 기준으로 약 167만원(Statistics Korea, 2015)임을 고려 할 때, 월평균가구소득이 300 만원 미만인 가정의 어머니는 가 정의 생계 및 기본적 생활유지를 위해 신경을 써야 하고 나아 가 자녀에게 필요한 기본적인 환경조성 마련에 요구되는 비용 을 부족하게 여겨 자녀를 잘 양육할 수 있다는 믿음이 낮아진 다고 해석해 볼 수 있다. 그러나, 이에 대한 보다 분명한 이해 를 위해 추후의 연구를 통해 확인해 나가야 할 것이다.

둘째, 아버지의 양육참여 및 부부 의사소통과 어머니 양육 효능감 간의 관계를 살펴본 결과, 아버지 양육참여의 하위요 인은 어머니 양육효능감 및 부부 의사소통과 정적상관을 나 타냈으며, 부부 의사소통도 어머니의 양육효능감과 정적 상 관관계를 나타냈다. 즉, 아버지가 가정에서 자녀의 생활지도 나 가사 및 여가활동에 많이 참여할수록, 어머니의 양육효능 감은 높게 나타났으며, 부부간에 긍정적이며 효율적인 의사소 통을 더 많이 했다. 또한, 부부간에 더 긍정적이고 효율적인 대 화를 할수록 어머니의 양육효능감도 높게 나타났다. 이는 아 버지의 양육참여는 어머니의 양육효능감에 영향을 미쳤다는 연구(Krishnakumar \& Buehler, 2000) 및 남편의 가사활동 참여 가 어머니의 양육태도에 영향을 미쳤다는 선행연구(B. S. Kim, 2011)와 유사한 결과로, 아버지가 가사나 육아에 참여하는 비 중이 높을 때 어머니는 이를 다른 사회적 관계에서 제공될 수 없는 지원으로 여기며, 이를 토대로 형성된 부부관계를 통해
어머니의 적절한 양육행동이 나타날 수 있다는 연구(Belsky, 1984)와 유사하다. 즉, 유아기 자녀를 둔 어머니에게 자녀를 돌보며 동시에 가사활동을 모두 다 잘 해낸다는 것은 현실적 으로 어려운 일로, 아버지가 자녀와 놀아주며, 가사에 참여하 고, 가족과 외출하거나 함께 보내는 시간을 마련하는 등의 직 접적인 지원을 할 때, 어머니는 육아 부담감이 줄어들 뿐 아니 라, 이러한 남편의 참여적 행동은 어머니의 육아에 대한 자신 감을 향상시키고, 양육을 잘할 수 있을 것이라는 믿음을 갖게 한다고 해석할 수 있다. 따라서, 이 시기 가정에서 아버지가 가 사활동에 참여가 어려운 여건일 때, 어머니의 가사활동을 보 조하는 사회 복지시스템 마련이 필요하며, 어머니는 주위의 사회적 자본을 최대한 활용하는 것이 필요할 것이다.

또한, 아버지의 양육참여가 부부간의 긍정적 의사소통을 향상시켰다는 결과는, 두 변인을 직접 조사한 연구가 없어서 비교하기 어렵지만, 종단연구를 통해 나타난 바와 같이, 어머 니가 아버지의 양육참여를 높게 인식할 때 어머니의 결혼만족 도가 높았다는 연구(Seo, 2017) 및 손이 많이 가는 영유아기의 자녀를 둔 가정에서 아버지의 양육참여는 자녀양육과 관련한 어머니의 양육부담감을 줄여주고, 부부관계와 결혼생활의 만 족에 영향을 준다는 연구(J. J. Kim, \& Kim, 2007)와 같은 맥락 으로 이해할 수 있다. 반대로, 남편의 양육참여가 소홀하다고 여기는 어머니는 남편이 가정에 관심이 적거나 자신을 잘 이 해해주지 않는다고 여기게 되어 부부관계에도 어려움을 겪는 것(J. S. Lee, 2003)으로 이해할 수 있다. 이러한 결과는 유아기 자녀를 둔 어머니는 자녀 양육뿐 아니라 교육과 훈육에도 관 심을 가지는 시기로 해야 할 일이 늘면서 에너지가 부족하다 고(Doh et al., 2011) 여기기 쉽기 때문이다. 따라서, 이 시기 어 머니가 자녀를 양육하면서 남편이 양육참여에 소극적이라고 여기면 남편이 비협조적이며 양육에 관심이 없거나 자신을 이 해해주지 못하는 것으로 지각하며, 대개 이러한 어머니는 남 편과 상호 의사소통하는 과정에서 긍정성이 낮은 의사소통방 식을 사용한다고 해석할 수 있다.

한편, 부부간에 긍정적인 의사소통을 할수록 어머니의 양 육효능감이 높았다는 결과는, 부부간의 긍정성이 낮은 의사 소통은 어머니의 양육효능감을 낮추었다는 연구(Planalp \& Braungart-Rieker, 2016)와 일치하며, 부부가 결혼에 만족할 때 부모의 효능감은 증가했다는 연구(A. R. Lee, 2015) 및 부부간 의 관계가 견고할수록 양육행동이 민감하고 적극적이며 부모 로서의 능력도 높게 지각한 반면, 부부관계가 불안정할 때 강 제적인 양육행동을 취하거나 양육스트레스가 높았다는 연구 (Emery \& Tuer, 1993)와 유사한 맥락으로 이해할 수 있다. 이는 
부부간에 서로를 이해하고 존중하며 어려움을 함께 의논하는 등의 긍정적인 대화를 할 경우, 이 시기 유아기 자녀를 둔 아내 는 남편의 이해와 배려를 통해 자녀 양육에 대한 자신감을 느 끼게 되며, 육아를 잘 할 수 있다는 자신에 대한 믿음도 증가한 다고 이해할 수 있다.

셋째, 아버지의 양육참여와 어머니의 양육효능감 간의 관 계에서 부부 의사소통의 조절효과를 살펴본 결과, 두 개의 유 의한 결과가 나타났다. 먼저, 아버지의 생활지도와 어머니의 양육효능감 간의 관계에서 부부 의사소통의 조절효과가 나타 났다. 아버지가 유아기 자녀의 생활지도에 많이 참여할 경우, 부부 의사소통의 긍정성 수준이 높은 집단은 긍정성 수준이 낮은 집단에 비해 더 높은 어머니의 양육효능감을 보이고 있 으며, 아버지가 유아기 자녀의 생활지도에 적게 참여할 경우 에도 부부 의사소통의 긍정성 수준이 높은 집단은 긍정성 수 준이 낮은 집단에 비해 더 높은 어머니의 양육효능감을 나타 내고 있다. 또한, 아버지의 여가활동 참여와 어머니의 양육효 능감과의 관계에서도 같은 결과가 나타났는데, 아버지의 여가 활동 참여가 어머니의 양육효능감에 미치는 영향에 부부 의사 소통의 상호작용이 나타나, 부부 의사소통의 수준에 따라 아 버지의 여가활동 참여가 어머니의 양육효능감에 미치는 영향 이 달라졌다. 즉, 아버지가 유아기 자녀의 여가활동에 많이 참 여할 경우, 부부 의사소통의 긍정성 수준이 높은 집단은 긍정 성 수준이 낮은 집단에 비해 더 높은 어머니의 양육효능감이 나타났다. 또한, 아버지가 유아기 자녀의 여가활동에 적게 참 여할 경우에도 부부 의사소통의 긍정성 수준이 높은 집단은 긍정성 수준이 낮은 집단에 비해 더 높은 어머니의 양육효능 감을 보였다. 이는, 같은 수준으로 아버지가 자녀의 생활지도 나 여가활동에 참여해도, 부부 의사소통의 긍정성 수준이 높 을수록 어머니의 양육효능감이 더 높다는 것을 의미한다.

유아기 자녀를 둔 가정의 아버지 양육참여가 어머니의 양 육효능감에 미치는 영향, 그리고 부부 의사소통의 중재적 역 할을 조사한 연구가 없어서 직접적인 비교는 어렵지만, 아버 지가 양육에 적극적으로 참여할수록 어머니의 양육효능감이 높았으며(Cho, 2015), 아버지가 자녀의 양육에 적극적일 때 부 부간의 결혼만족도는 높았고 지지적이고 신뢰적인 관계를 기 초로 긍정적인 양육행동을 이끌어내며(N. S. Kim, 2009), 어 머니의 심리적 안정을 도모하여 양육에 대한 긍정적인 믿음 을 갖게 했다는 연구(J. J. Kim \& Kim, 2007)와 유사하다. 반대 로 아버지의 양육참여가 적을 때 어머니는 자녀를 잘 기를 수 있다는 믿음이 약해지며(Cho, 2015), 아버지의 낮은 양육참 여로 결혼만족도 수준이 낮으면 어머니의 무기력증이 증가하
고 이러한 정서는 양육에 대한 부담과 스트레스를 더 증폭시 킴으로써, 양육효능감에 부정적인 영향을 미쳤다(Sevigny \& Loutzenhiser, 2010)는 연구와 유사한 맥락으로 이해할 수 있다. 또한, 남편이 육아에 참여를 많이 하거나 가사 일을 돕고 가족 들과 여가활동을 함께 보낼 때, 어머니의 양육부담감을 줄여 주고, 배우자에 대한 만족감을 높여주며(Ahn, 2011), 배우자와 의 관계에 만족도가 큰 경우, 자녀 양육에 대한 자신감도 높았 다는 연구(A. R. Lee, 2015)를 통해서도 이해해볼 수 있다. 즉, 양육과 교육으로 부모의 손길이 많이 요구되는 유아기 자녀를 둔 가정에서 어머니의 몫으로만 생각되었던 자녀의 일상생활 을 지도하거나, 가족과 함께 보내는 시간을 마련하는 등의 일 상적 여가와 관련한 부분에서 아버지들의 직접적인 양육참여 는, 자녀 양육과 관련한 어머니의 양육부담감을 줄여주며, 이 때 높아진 배우자에 대한 만족감은 부부간에 긍정적 요소로 작용하여(Belsky, 1984) 보다 원만하고 효율적인 의사소통이 이루어지며 긍정성이 높은 의사소통은 어머니의 양육효능감 을 높였다(Planalp \& Braungart-Rieker, 2016)고 이해해 볼 수 있 다. 남편과의 의사소통의 긍정성 정도가 아버지 양육참여가 어머니의 양육효능감에 미치는 영향을 중재할 수 있는 요인이 된다는 본 연구결과는, 한창 사회활동이 많아 가정 밖에서 많 은 시간을 보내는 유아기 자녀를 둔 30,40 대 아버지들에게 의 미하는 바가 크다. 즉, 직장생활로 가정 내의 양육참여가 쉽지 않은 아버지들의 경우, 특히, 아내와의 긍정적이고 효율적인 의사소통의 중요성을 인식할 필요가 있다. 또한, 사회에서도 유아기 자녀를 둔 부부가 서로 이해하는 자세를 통해 상호 긍 정적인 의사소통을 할 수 있도록 돕는 부부교육이나 사회교육 프로그램을 체계적으로 실시하는 방안 모색이 필요함을 보여 준다. 나아가, 본 연구결과는 바람직한 부부 의사소통 방식에 관한 교육뿐 아니라, 사회에서도 유아기 자녀를 둔 아버지의 양육참여가 중요하다는 인식을 제고할 필요가 있음을 보여준 다. 아버지 육아휴직제도의 활성화, 탄력근무제의 제도 마련 및 유럽에서 유행하는 ‘라떼파파'처럼 육아는 어머니만의 몫 이라는 인식에서 벗어나 부모가 함께 해나가야 할 과정이라는 사회적 인식의 확산이 필요하며, 우리 사회에서도 아버지의 육아참여를 격려하는 문화 조성과 국가 정책적 지원이 필요할 것이다.

이상의 연구결과들을 종합하면, 교육과 양육 등의 돌봄이 요구되는 유아기 자녀를 둔 가정에서 남편의 육아 및 여가활 동 참여가 어머니의 양육효능감에 미치는 영향은, 부부간 의 사소통이 효율적이고 긍정적인지에 따라 달리 나타난다고 할 수 있다. 즉, 어머니의 양육효능감은 유아기 자녀를 둔 가정 내 
에서 직장생활로 바빠 아버지가 자녀의 일상생활 활동을 돕거 나, 여가활동에 참여하기 어려운 상황일 때, 부부간에 서로를 이해하고 배려한다고 여기는 긍정적 의사소통을 할 때 완충 될 수 있다는 것을 보여준다. 이와 더불어, 아버지의 가사활동 참여도 어머니의 양육효능감과 관련된다는 본 결과는 '현실육 아'의 관점에서 어머니에게 일상적으로 일어나는 가사활동의 보조나 그 부담을 덜어주는 여건 마련이 중요하며 현실적 대 책 마련이 시급함도 나타내고 있다.

끝으로 본 연구의 제한점을 기초로 후속연구를 위한 제언 을 하면 다음과 같다. 첫째, 본 연구에서는 3세 5세의 유아기 자녀를 둔 어머니를 대상으로 이 시기 자녀 양육 과정에서 형 성되는 양육효능감과 남편의 양육참여 등 그 관련 변인의 관 계를 조사하였으나, 추후의 연구에서는 자녀의 기질 및 발달 적 특성 등 자녀관련 변인도 함께 고려해 보는 것도 필요할 것 이다. 둘째, 아버지의 양육참여는 어머니가 지각한 아버지의 자녀 생활지도, 가사 및 여가활동 참여를 통해 측정하였다. 그 러나, 본 측정도구에는 일상적 돌봄과 같은 주양육자의 자녀 양육 시 나타나는 활동이 모두 포함되지 않았다. 따라서, 아버 지의 실질적 양육참여를 파악하는 데에 한계가 있었다. 이후 의 연구에서는 아버지의 양육참여를 묻는 질문지 내용을 보다 구체화하여 실제 참여 정도를 파악할 필요가 있을 것이다. 이 는 어머니의 지각과 아버지가 실제 참여한 양과 질의 측면이 다를 수 있기 때문이다. 셋째, 부부 의사소통 질문지는 어머니 에 의해 측정되었다. 부부간의 의사소통 내용을 지각하는 데 에 차이가 있을 수 있으므로 추후의 연구에서는 아버지에 의 한 평가도 조사하여 분석하는 것이 필요할 것이다. 끝으로, 본 연구의 대상은 서울시 $\mathrm{D}, \mathrm{Y}$ 구에 위치한 어린이집들로 한정되 어, 본 연구결과를 일반화하기에는 다소 무리가 있다. 따라서 추후의 연구는 더욱 폭넓은 지역으로 표집 대상 범위를 확대 하여 시행할 필요가 있다.

이러한 제한점이 있으나, 본 연구를 통해 나타난 몇 가지 의 의를 제시하면 다음과 같다. 먼저, 유아기 자녀를 둔 가정 내의 아버지 양육참여 및 부부 의사소통과 어머니의 양육효능감이 어떻게 관련되는지를 조사하였다. 이는 자녀 양육 시에 중요 한 어머니의 심리 내적 신념체계인 양육효능감 향상은, 아버 지 양육참여의 도움이 크며, 특히, 부부간에 보다 효율적이고 긍정적인 대화를 할 때 안정적이며 증진될 수 있다는 것을 보 여준 결과로써, 이 시기 부모 혹은 부부교육의 중요성을 강조 했다. 즉, 자녀가 교육기관에 다니는 시기인 만큼 교육기관에 서의 부모 및 부부교육을 온, 오프라인을 통해 체계적으로 제 공하는 것이 필요할 것이다. 또한, 각 가정의 상황에 따라 아버
지 양육참여가 어려울 때, 부부간에 서로 이해하고 배려하는 긍정적 의사소통으로 어머니의 양육효능감이 달라질 수 있다 는 점을 확인함으로써, 어머니 양육효능감 향상 변인으로 부 부 의사소통의 영향력을 밝혔다. 또한, 이러한 결과는 아버지 양육참여에 관한 사회나 기업의 인식이 부족한 우리 사회에서 아버지 양육참여가 부족할 때 야기될 수 있는 어머니 양육효 능감 감소의 위험성을 낮추기 위해, 부부간의 적극적이고 배 려하는 의사소통이 중요함을 강조했다. 즉, 실천적인 측면에 서 남편이 육아하는 아내의 어려움을 이해해주고 의논의 상대 가 되어 격려해 주는 것의 중요성을 확인한 결과로써, 유아기 자녀를 둔 어머니의 상황에 관한 이해 및 공감적이고 개방적 인 대화방식의 실제를 내용으로 한 부부 의사소통 교육의 중 요성을 시사하였다.

\section{Conflict of Interest}

No potential conflict of interest relevant to this article was reported.

\section{References}

\section{In English}

Aiken, L. S., \& West, S. G. (1991). Multiple regression: Testing and interpreting interactions. Newbury Park, CA: Sage.

Baron, R. M., \& Kenny, D. A. (1986). The moderator-mediator variable distinction in social psychological research: Conceptual, strategic, and statistical considerations. Journal of Personality and Social Psychology, 51(6), 1173-1182. doi:10.1037//0022-3514.51.6.1173

Belsky, J. (1984). The determinants of parenting: A process model. Child Development, 55(1), 83-96. doi:10.2307/1129836

Belsky,J., Crnic, K., \& Wookworth, S. (1995). Personality and parenting: Exploring the mediating role of transient mood and daily hassles. Journal of Personality, 63(4), 905-929. doi:10.1111/j.1467-6494.1995.tb00320.x

Berry, W. D., \& Feldman, S. (1985). Multiple Regression in Practice. London: Sage Publications. doi:10.4135/9781412985208

Coleman, P. K., \& Karraker, K. H. (1997). Self-efficacy and parenting quality: Findings and future applications. Developmental Review, 18(1), 47-85. doi:10.1006/ drev. 1997.0448

Coleman, P. K., \& Karraker, K. H. (2003). Maternal self-efficacy 
beliefs, competence in parenting and toddler's behavior and developmental status. Infant Mental Health Journal, 24(2), 126-148. doi:10.1002/imhj.10048

Dorsey, S., Klein, K., Forehand, R., \& Family Health Project Research Group. (1999). Parenting self-efficacy of HIVinfected mothers: The role of social support. Journal of Marriage and Family, 61(2), 295-305. doi:10.2307/353749

Emery, R. E. , \& Tuer, M. (1993). Parenting and the marital relationship. In Luster, T. \& Okagaki, L. (Eds). Parenting an ecological perspective (pp. 121-148), Hillsdale, NJ: Lawrence Erlbaum associates.

Goldberg, W. A. \& Easterbrooks, M. A. (1984). Role of marital quality in toddler development. Developmental Psychology, 20(3), 504-514. doi:10.1037/0012-1649.20.3.504

Krishnakumar, A., \& Buehler, C. (2000). Interparental conflict and parenting behaviors: A meta-analytic review. Family Relations, 49(1), 25-44. doi:10.1111/j.1741-3729.2000.00025.x

Planalp, E. M., \& Braungart-Rieker, J. M. (2016). Determinants of father involvement with young children: Evidence from the early childhood longitudinal study-birth cohort. Journal of Family Psychology, 30(1), 135-146. doi:10.1037/ fam0000156

Ponnet, K., Mortelmans, D., Wouters, E., Leeuwen, K. V., Bastaits, K., \& Pasteels, I. (2013). Parenting stress and marital relationship as determinants of mothers' and fathers' parenting. Personal Relationships, 20(2), 259-276. doi:10.1111/j.14756811.2012.01404.x

Satir, V. (1972). Peoplemaking. Palo Alto, CA: Science \& Behavior Books. doi:10.1038/235053a0

Sevigny, P. R. \& Loutzenhiser, L. (2010). Predictors of parenting self-efficacy in mothers and fathers of toddlers. Child: Care, Health and Development, 36(2), 179-189. doi:10.1111/ j.1365-2214.2009.00980.x

Spanier, G. B. (1979). Measuring dyadic adjustment: New scales for assessing the quality of marriage and similar dyads. Journal of Marriage and the Family, 38(1), 15-28. doi:10.2307/350547

Teti, D. M., \& Gelfand, D. M. (1991). Behavioral competence among mothers of infants in the first year: The mediational role of maternal self-efficacy. Child Development, 62(5), 918-929. doi: $10.2307 / 1131143$

\section{In Korean}

Ahn, J. J. (2011). The effect of father's child rearing involvement on mother's parenting stress in early years: focusing on the mediating role of marital relationship. Journal of the Korean Society of Child Welfare, 35(1), 127-158.

Ahn, J. Y. (2000). The effects of maternal parental beliefs, efficacy and stress on mother's parenting behaviors (Doctoral dissertation).
Retrieved from http://www.riss.kr/link?id=T7991207

An R. R \& Kim, J. A. (2005). The relationship between mother's parenting efficacy, parenting stress, children's daily stress, and peer competence. Journal of Educational Studies, 36(1), 329-350.

Cho S. H. (2015). Child-rearing efficacy, stress, and attitudes among parents of young children (Master's thesis). Retrieved from http://www.riss.kr/link?id=T13712303

Choi, K. S. (1992). (A)study on the relationship between social competency of child and the child rearing behaviors and involvement of father (Doctoral thesis). Retrieved from http://www.riss.kr/link?id=T1289854

Chung, K.-S., Kim, M.-J., \& Ha, E.-S. (2012). The relationships between maternal happiness, parenting competence and ego-resiliency of young children. The Journal of Korea Open Association for Early Childhood Education, 17(1), 73-97.

Chung, M. R., Kim, M. J., \& Yee, B. S. (2015). The relationship between maternal gatekeeping and paternal parenting: The mediating effects of marital communication. Korean Journal of Childcare and Education, 11(2), 355-373. doi:10.14698/ jkcce.2015.11.355

Doh, H. S., Lee, H. S., Kim, S. H., Choi, M. K., Lee, S. R., \& Kim, S. W. (2011). Human development and the family. Paju, Kyeongi: Kyomunsa.

Ha M. J. \& Jang Y. A. (2010). The effect of parenting efficacy, parenting stress on self-efficacy and daily stress among elementary school children. The Korean Journal of Community Living Science, 21(1), 33-51.

Hong, S. H. (2005). Binary and a multiple logistic regression analysis. Seoul: Educational science company.

Hong, Y-J., \& Yi S-H. (2017). Links among parenting stress, family cohesion and family flexibility of mothers with young children: The moderating effect of the parenting role-sharing with fathers. Korean Journal of Child Care and Education Policy, 11(1), 105-125. doi:10.5718/ kcep.2017.11.1.105

Kim, B. S. (2011). The effects of father's participation in the care of their children on mother's parenting efficacy and parenting behavior (Master's thesis). Retrieved from http://www.riss. $\mathrm{kr} /$ link?id=T12352644

Kim, C. J. \& Son Y. S. (2011). The control of administrative discretion in decision of the minimum cost of living, Kyungpook National University Law Journal, 35, 255-298. doi:10.17248/knulaw..35.201102.256

Kim, E., Park, S. \& Kim. K. (2014). A longitudinal study of the effects of father involvement and marital conflict on mother's parenting stress. Korean Journal of Child Care and Education Policy, 8(1), 129-151.

Kim, J. J, Kim, Y. M. (2007). The relationship between fathering practices, father's marital satisfaction, and mother's 
parenting efficacy. The Journal of Korea Child Care and Education, 50(1), 113-137.

Kim, N. S. (2009). The effect of multi-cultural family mothers' stress, social support, marital satisfaction on child caring (Master's thesis). Retrieved from http://www.riss.kr/ link?id=T11796337

Lee, A. R. (2015). The moderating effects of marital satisfaction on the relationship between preschoolers' temperament and mothers' parenting efficacy (Master's thesis). Retrieved from http:// www.riss.kr/link?id=T13844163

Lee, J. S. (2003). Fathers of preschool children: childrearing involvement, husband-wife relationship and growth as a parent. Journal of Child Studies, 24(3), 99-108.

Lee, J. S. \& Doo, J. I. (2008). The effects of preschooler's adaptive temperament and father's child-rearing involvement on mother's child-rearing stress. Korean Journal of Child Psychotherapy, 3(2), 1-17.

Lee, S. S. (2016). The effect of stress on parents with high-risk infants and the role of marital communication and spousal support in parental adjustment (Master's thesis). Retrieved from http:// www.riss.kr/link?id=T14450320

Seo, M. J. (2017). Longitudinal relevance between mother's perceived father involvement and marital satisfaction for fathers and mothers. Journal of Child Care and Education,
11(3), 47 64. doi: 10.5718/kcep.2017.11.3.47

Statistics Korea. (2015). 4ingagu choejeosaenggyebi (KOSIS 100daejipyo)[4인가구 최저생계비(KOSIS 100대지표)]. Retrieved from KOSTAT website: http://kostat.go.kr.

The Asia Business Daily. (2014). matbeorineun isseodo majyuganeun eopdeora[맞벌이는 있어도 맞육아는 없더라]. Retrieved March 11, 2014, from http://www.asiae.co.kr

Yoon, S. H. \& Sung, J. H. (2014). The effects of mothers' parenting efficacy on children's emotional regulation: The moderating effects of mothers' perception of fathers' involvement in child care. Korean Journal of Child Studies, 35(4), 199-222. doi:10.5723/kjcs.2014.35.4.199

\section{ORCID}

Mi-Kyoung Choi http://orcid.org/0000-0001-6026-1374

Received June 30, 2018

Revision received August 1, 2018

Accepted October 21, 2018 